\title{
Luxury Uptake and Removal of Phosphorus from Water Column by Representative Aquatic Plants and Its Implication for Wetland Management
}

\author{
Shardendu Shardendu, ${ }^{1}$ D. Sayantan, ${ }^{1}$ Deepti Sharma, ${ }^{1}$ and Sufia Irfan ${ }^{2}$ \\ ${ }^{1}$ Laboratory of Environment and Biotechnology, Department of Botany, Patna Science College, Patna University, Patna 800005, India \\ ${ }^{2}$ Department of Biology, University of Tabuk, Tabuk 71421, Saudi Arabia
}

Correspondence should be addressed to Shardendu Shardendu, shardendu.loeb@gmail.com

Received 15 December 2011; Accepted 10 January 2012

Academic Editors: J. Artiola, Z. L. He, and W. Peijnenburg

Copyright () 2012 Shardendu Shardendu et al. This is an open access article distributed under the Creative Commons Attribution License, which permits unrestricted use, distribution, and reproduction in any medium, provided the original work is properly cited.

\begin{abstract}
Aquatic plants with their high relative growth rates efficiently absorb nutrients from their surrounding media, thereby providing a simple and inexpensive solution for nutrient-polluted aquifers. The present study determined the $\mathrm{P}$ accumulation efficiencies of four different aquatic plants namely, Eleocharis plantaginea, Eichhornia crassipes, Pistia stratiotes, and Hydrilla verticillata from the 6043 ha Kabar Wetland $\left(86^{\circ} 05^{\prime} \mathrm{E}\right.$ to $86^{\circ} 09^{\prime} \mathrm{E}, 25^{\circ} 30^{\prime} \mathrm{N}$ to $\left.25^{\circ} 32^{\prime} \mathrm{N}\right)$. The aim of the study was to select the most efficient $\mathrm{P}$ accumulator. Water, sediment, and plant samples from Kabar were monthly analyzed for P content for 13 months from July 2009 to July 2010. Pistia stratiotes L. accumulated the highest amount of tissue P ( $1.06 \pm 0.22 \mathrm{mg} / \mathrm{g} \mathrm{dw})$. The maximum capacity of luxury uptake of $\mathrm{P}$ under greenhouse conditions as exhibited by Pistia was further tested. Pistia individuals tolerated up to $50 \mathrm{mg} / \mathrm{L}$ phosphate medium and accumulated $6.12 \pm 0.95 \mathrm{mg} / \mathrm{g} \mathrm{dw} \mathrm{P}$ after 35 days under greenhouse conditions. Up to $91 \%$ phosphate was removed from the surrounding medium within 60 days at $50 \mathrm{mg} / \mathrm{L}$ supply. Tissue P levels increased with increasing phosphate levels in the surrounding media but variation with incubation period was statistically insignificant. Our studies present Pistia as more efficient than other common wetland species like Eichhornia, Phragmites, Typha, and so forth when grown in the sub-tropics and confirm its ability to ameliorate P-polluted subtropical wetlands.
\end{abstract}

\section{Introduction}

Recently, environmental scientists and policy makers are equally concerned to manage wetlands for mainly two reasons; firstly, the wetlands provide many important goods and services to human societies, ranging from flood control and nutrient removal to fish products and recreational, activities, and secondly, wetlands are the sensitive ecosystems that are subject to stress from human activities. Uptake, accumulation and harvesting the excess water nutrients through plants may be a key factor in mitigating the stress and improving management of wetlands. Wetlands are the known depositories of nutrients, including phosphorus, and many times used as filters, thereby preventing their efflux into larger water bodies and maintaining the water quality downstream [1]. The global biogeochemical cycle of $\mathrm{P}$ is complex and involves several activities like weathering of rocks, river discharge, sedimental rate, and uptake by the biotic components of terrestrial and aquatic ecosystems [2]. With no stable gaseous phosphorus compounds, the global phosphorus cycle majorly involves the lithosphere and the hydrosphere.

In the aquatic environment $\mathrm{P}$ may be encountered in several forms, among which are dissolved inorganic $\mathrm{P}$ (DIP), particulate inorganic P (PIP), dissolved organic P (DOP), and particulate organic $\mathrm{P}$ (POP) [3]. The concentration of DIP and DOP remain characteristically higher in water than in soils because of the lower levels of potential phosphorus immobilizing agents like iron, aluminium, and calcium [4]. Among the various forms of $\mathrm{P}$, the most readily bioabsorbed form is DIP, the other forms must undergo transformation to the dissolved inorganic form before they can be utilized by the aquatic flora $[1,4,5]$. $\mathrm{P}$ is a macronutrient considered essential for floral life to flourish. In the plant body, P gets 


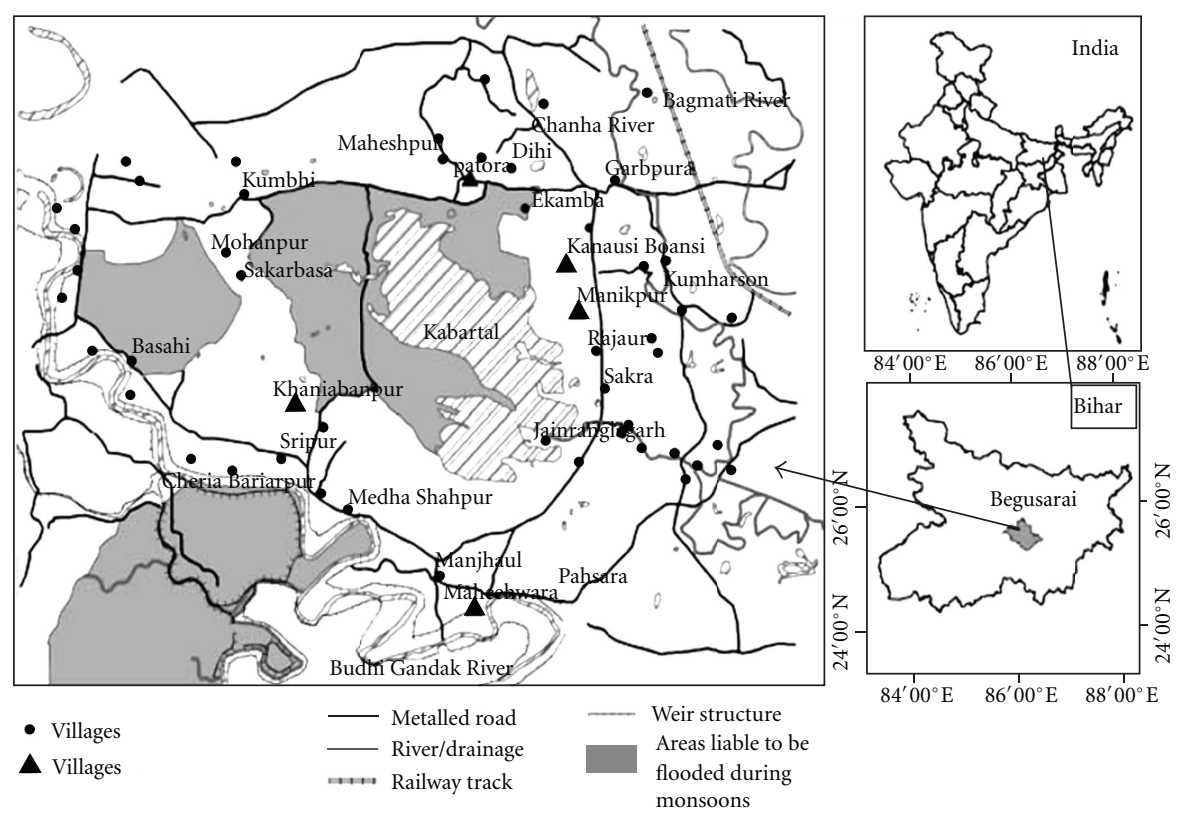

FIgURE 1: Study site: Kabar wetland.

accumulated as polyphosphates [6-8]. These polyphosphates are either acid soluble, in which case they are mainly used for metabolism and production of DNA and proteins, or acid insoluble polyphosphates [9-11], which are stored in the biomass of plants and utilized at the time of low external concentration $[8,12]$. This indicates the importance of phosphate for growth and metabolism. This further brings into sharp focus the aquatic macrophytes that with their high growth rates $[13,14]$ may serve as efficient phosphate biosorbent in their surrounding media. Aquatic macrophytes have been previously reported to efficiently absorb other nutrients like nitrogen [15] and $\mathrm{NO}_{3}{ }^{-}, \mathrm{PO}_{4}{ }^{3-}, \mathrm{K}, \mathrm{Ca}, \mathrm{Mg}$, and $\mathrm{Na}$ [16]. P uptake by aquatic macrophytes like Hydrilla verticillata and Myriophyllum spicatum [17], Zostera marina [18], Egeria densa [19], Eichhornia crassipes and Lemna obscura [20], Phragmites australis [21], Typha [22] and Pistia stratiotes [23, 24], and so forth have also been previously demonstrated.

Presence of excess $\mathrm{P}$ in wetlands is decidedly harmful, causing toxic algal blooms, low dissolved oxygen, fish kills and loss of aquatic biodiversity, and seriously undermining environmental quality and human well being. In this condition, phenomenon of luxury uptake of phosphorus is observed among the flora of wetlands which majorly include microalga $[6,12,25,26]$, sediment bacteria $[27,28]$, and aquatic macrophytes [22]. Luxury uptake has been defined as the uptake of $\mathrm{P}$ by an organism from its $\mathrm{P}$ enriched growth medium, where prior starvation stage by the species is not required [7]. Essentially, the amount of $\mathrm{P}$ taken up is more than that released by the organisms, resulting in net removal of $\mathrm{P}$ from the surrounding medium [29]. This indicates that luxury uptake of $\mathrm{P}$ by aquatic macrophytes should be investigated in greater detail with the aim of standardizing the process for ridding nutrient-polluted aquifers of their excess phosphate load. The present study attempts to investigate the P uptake capacity of four common aquatic plant species, namely, Eleocharis plantaginea, Eichhornia crassipes, Pistia stratiotes, and Hydrilla verticillata in their natural habitat, the Kabar wetland $\left(25^{\circ} 35^{\prime} \mathrm{N} ; 86^{\circ} 10^{\prime} \mathrm{E}\right)$, Kabar is a large subtropical wetland in the Gangetic plain of eastern India. The initial study involves the monitoring of the wetland water, sediment and the four selected plant species for their phosphate and/or total P (TP) contents. Later, the P uptake in natural versus greenhouse conditions as exhibited by the highest $\mathrm{P}$ accumulator has been assessed.

\section{Materials and Methods}

2.1. Details of Study Area and Sample Collection. Kabar $\left(25^{\circ} 35^{\prime} \mathrm{N} ; 86^{\circ} 10^{\prime} \mathrm{E}\right)$ is a residual ox-bow lake of great local significance located in the Eastern Gangetic Plain (Figure 1). It is the largest wetland in the north of the Bihar province of India spanning an area of 6043 ha in 2002 [30]. It is a major migratory bird reserve and was declared a Protected Area in 1986. Kabar has been found to be constituted mainly of paddy fields. Despite its immense ecological import, Kabar is under extreme anthropogenic pressure. Currently it receives the agricultural runoff of nearly thirty odd surrounding villages.

The monthly variation in the $\mathrm{P}$ contents of Kabar surface water, water at $1 \mathrm{~m}$ depth and in the sediment (at $0.5 \mathrm{~cm}-$ $1 \mathrm{~cm}$ depth), was determined. Also, four common plant species present in the wetland, namely, Eleocharis plantaginea, Eichhornia crassipes, Pistia stratiotes, and Hydrilla verticillata were sampled and tested for $\mathrm{P}$ accumulation in their tissues. These plants were selected as they represented the three individual niches in an aquatic habitat: submerged (Hydrilla verticillata), emergent (Eleocharis plantaginea), and floating (Eichhornia crassipes, Pistia stratiotes). The sampling 
and analysis were carried out for a period of 13 months, beginning July 2009 and ending July 2010. For efficient sampling, Kabar was divided into 4 imaginary plots. Within each plot, random sampling was carried out to cover the span of the study area. Surface water and water at $1 \mathrm{~m}$ depth were collected by $1 \mathrm{~L}$ water samplers (SP100 Global Water Instrumentation, Inc.). Sediment samples were collected using long-handled metal ladles that had been pre-graduated to determine the depth from which sediment was taken. Samplers and ladles were washed with phosphate-free detergents and given a dilute nitric acid rinse followed by a deionized water rinse. Samples were brought to the laboratory within 4 hours and analyzed the same day. All samples were collected and analyzed in triplicates.

2.2. Sample Digestion and P Measurement. Water and sediment samples were digested to convert all forms of $\mathrm{P}$ into orthophosphate. Water samples were digested as per Ebina et al. [31] with $5 \mathrm{~mL}$ water and $5 \mathrm{~mL}$ oxidizing solution ( $20.0 \mathrm{~g}$ potassium persulfate and $3.0 \mathrm{~g}$ sodium hydroxide in $1 \mathrm{~L}$ water) autoclaved at $120^{\circ} \mathrm{C}$ for 30 minutes. Sediment and plant samples were first dried at $100^{\circ} \mathrm{C}$ in a drought oven for 72 hours, powdered, and then filtered through a 40 mesh. These samples were then digested as per Langner and Hendrix [32] taking $15 \mathrm{mg}$ plant sample in $15 \mathrm{~mL}$ oxidizing solution $(20.1 \mathrm{~g}$ potassium persulfate and $9.0 \mathrm{~g}$ sodium hydroxide in $1 \mathrm{~L}$ water) and autoclaving for 2 hours at $120^{\circ} \mathrm{C}$. DIP contents in the digested samples were analyzed by the stannous chloride-ammonium molybdate method as per APHA [33]. To $10 \mathrm{~mL}$ samples $0.4 \mathrm{~mL}$ ammonium molybdate reagent and $0.05 \mathrm{~mL}$ stannous chloride reagents were added and incubated for 11 minutes. The blue colour that developed was measured in a doublebeam UV-visible Spectrophotometer (Systronics 2202, New Delhi).

2.3. Greenhouse Culture and Experimental Design. Healthy and fresh individuals of Pistia stratiotes L. of approximately same size (number of leaves per plant $-8 \pm 2$, shoot length $-11.3 \pm 1.2 \mathrm{~cm}$, root length $-7.4 \pm 1.9 \mathrm{~cm}$, mean plant fresh weight $-12.23 \pm 3.21 \mathrm{~g}$ ) were selected from the Kabar wetland and brought to the greenhouse. Here, a mother culture of the plants was established and plants were acclimatized to the growth conditions for 30 days prior to the experiment.

For the experiment, Pistia individuals were cultured in experimental basins of surface area $0.375 \mathrm{~m}^{2}$ each with dimensions of $0.75 \mathrm{~m} \times 0.5 \mathrm{~m} \times 0.25 \mathrm{~m}$. For culturing the plants, Hoagland's nutrient solution with modifications [34] were used with the following composition $\left(\mu \mathrm{mol} \mathrm{L}^{-1}\right)$ : $\mathrm{Ca}\left(\mathrm{NO}_{3}\right)_{2} 200, \mathrm{KNO}_{3} 200, \mathrm{MgSO}_{4}$ 1000, Fe-NaEDTA 10, B 4.6, $\mathrm{Cl}$ 1.1, Mn 0.9, Zn 0.09, Mo 0.01. The nutrient solutions were renewed every 4 days. All chemicals used were of Merck (GR) grade. Pistia individuals were exposed to 7 increasing dosages of phosphate $(0.5,2.5,5,10,30$, and $50 \mathrm{mg} / \mathrm{L})$ supplied in the form of $\mathrm{NaH}_{2} \mathrm{PO}_{4} \cdot 2 \mathrm{H}_{2} \mathrm{O}$. Additional sodium citrate was added to each experimental basin to prevent chemical precipitation of phosphate as per Welch and Lindell

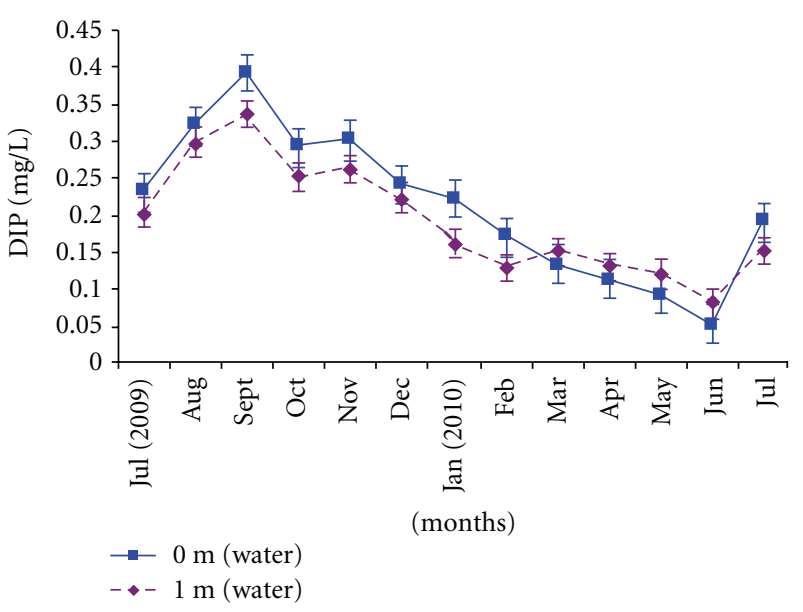

FIGURE 2: Monthly variation in dissolved inorganic phosphate (DIP $\mathrm{mg} / \mathrm{L}$ ) of Kabar water at $0 \mathrm{~m}$ and $1 \mathrm{~m}$ depth.

[4]. In the control tank, 301 of nutrient solution was provided without supplementary phosphate.

The environmental conditions during the study were temperature- $25 \pm 2^{\circ} \mathrm{C}, \mathrm{pH}-7.0 \pm 0.2$, light intensity4500-6000 lux, and photoperiod- $12 \mathrm{~h}$ daylight followed by $12 \mathrm{~h}$ of dark period. Evaporation of excess water from the experimental basins was made up for by adding distilled water.

Plants were harvested in triplicates after 7, 14, 21, 28, 35, 42 , and 60 days and analyzed for the accumulated P content. Residual DIP in each of the experimental basins was also determined at the same time periods when the plant harvests were made.

2.4. Statistical Analyses. Single factor ANOVA was used to analyze if the variations in the readings were statistically significant. Multiple regression equations demonstrated the extent of dependence of Pistia tissue P content, biomass increase, and residual phosphate in the experimental basins on supplied phosphate levels and incubation period. Correlation analysis between residual DIP in experimental basins and tissue P content of Pistia was performed to delineate that phosphate removal from the experimental basins was biological and not chemical. All the statistical tests were performed using STATISTICA v5.52.164.0 for Windows. All graphs were constructed using the software MICROSOFT OFFICE EXCEL (2003).

\section{Results}

3.1. P Contents of Kabar Water, Sediments, and Plants. The mean dissolved inorganic P (DIP) content of surface water of the Kabar wetland was $0.22 \pm 0.11 \mathrm{mg} / \mathrm{L}$ which was not much different from that recorded at $1 \mathrm{~m}$ depth $(0.2 \pm 0.09 \mathrm{mg} / \mathrm{L})$. The DIP content at both the water levels showed maxima of $0.4 \mathrm{mg} / \mathrm{L}$ in the month of October (Figure 2) at the surface $(0 \mathrm{~m}$ depth) and $0.38 \mathrm{mg} / \mathrm{L}$ at $1 \mathrm{~m}$ depth. The minima were observed in the month of June $(0.05 \mathrm{mg} / \mathrm{L}$ at the surface and $0.08 \mathrm{mg} / \mathrm{L}$ at $1 \mathrm{~m} \mathrm{depth}$ ) thus indicating that there was very 
TABLE 1: Statistical evaluation of variations in dissolved inorganic phosphate (DIP) and total P (TP) of Kabar water, sediment, and plant species using analysis of variance (ANOVA).

\begin{tabular}{|c|c|c|c|}
\hline \multirow{2}{*}{ Variable } & \multicolumn{3}{|c|}{ Sources of Variability } \\
\hline & Season & Depth & Species \\
\hline Mean DIP content at 0 and $1 \mathrm{~m}$ depth & 0.0000 & 0.5799 & - \\
\hline Mean TP content at 0 and $1 \mathrm{~m}$ depth & 0.0014 & 0.8200 & - \\
\hline Mean TP content in sediment & 0.0000 & - & - \\
\hline Mean TP content in plant species & 0.7016 & - & 0.0000 \\
\hline
\end{tabular}

Effects of season, depth, and plant species have been expressed as $P$ values. Values in bold indicate significant differences at $P<0.005$.

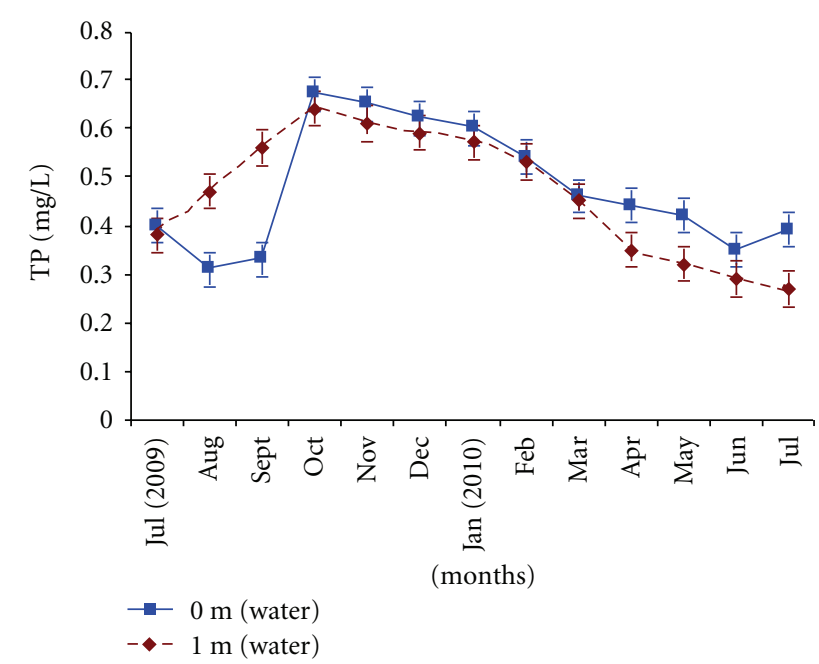

FIGURe 3: Monthly variation in total phosphorus (TP $\mathrm{mg} / \mathrm{L}$ ) of Kabar water at $0 \mathrm{~m}$ and $1 \mathrm{~m}$ depth.

little variation in DIP content across depth. The seasonal variation in DIP content of water at both the depths was highly significant $(P$ value $=0.0000)$ but variation across depth was not $(P$ value $=0.5799)($ Table 1$)$.

Total $\mathrm{P}$ contents for $0 \mathrm{~m}$ and $1 \mathrm{~m}$ depth also attained almost similar mean values of $0.47 \pm 0.13 \mathrm{mg} / \mathrm{L}$ and $0.45 \pm$ $0.14 \mathrm{mg} / \mathrm{L}$, respectively. The trend shown by TP content for water was similar to that shown by DIP at both 0 and $1 \mathrm{~m}$ depths. The TP attained maximum values in the month of October and dipped in July (Figure 3). At $0 \mathrm{~m}$ depth highest TP content was $0.67 \mathrm{mg} / \mathrm{L}$, while the lowest value was $0.29 \mathrm{mg} / \mathrm{L}$. At $1 \mathrm{~m}$ depth, the maximum and minimum values were 0.64 and $0.25 \mathrm{mg} / \mathrm{L}$, respectively. Here, too, variation across depth in the TP content was statistically insignificant $(P=0.9971)$ but was significant across seasons at $P<0.01$ (Table 1 ).

Mean TP content of Kabar sediment was measured as $0.74 \pm 0.27 \mathrm{~g} / \mathrm{kg}$. The P content peaked in the month of September $(1.35 \mathrm{~g} / \mathrm{kg})$ and dipped in January $(0.31 \mathrm{~g} / \mathrm{kg})$ (Figure 4). TP content in the sediment samples showed significant seasonal variation $(P=0.0000)$ (Table 1$)$.

Figure 5 depicts the monthly variation in the tissue $\mathrm{P}$ content of Eleocharis plantaginea, Eichhornia crassipes, Pistia stratiotes, and Hydrilla verticillata over the 1-year study

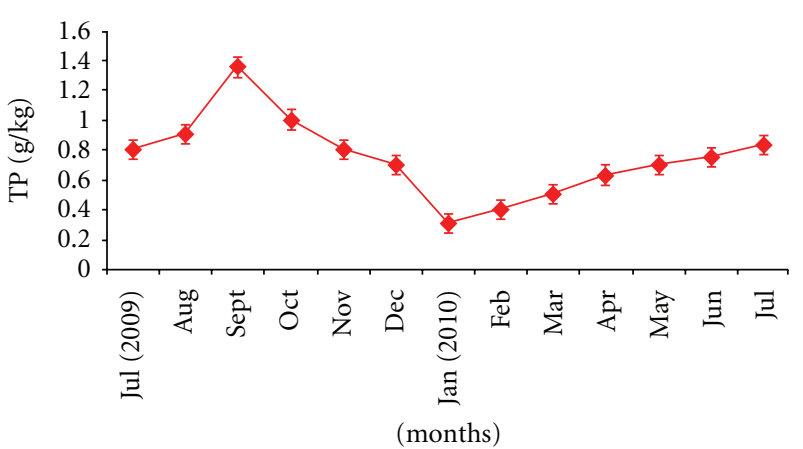

FIGURE 4: Monthly variation in total phosphorus (TP g/kg) of Kabar sediment.

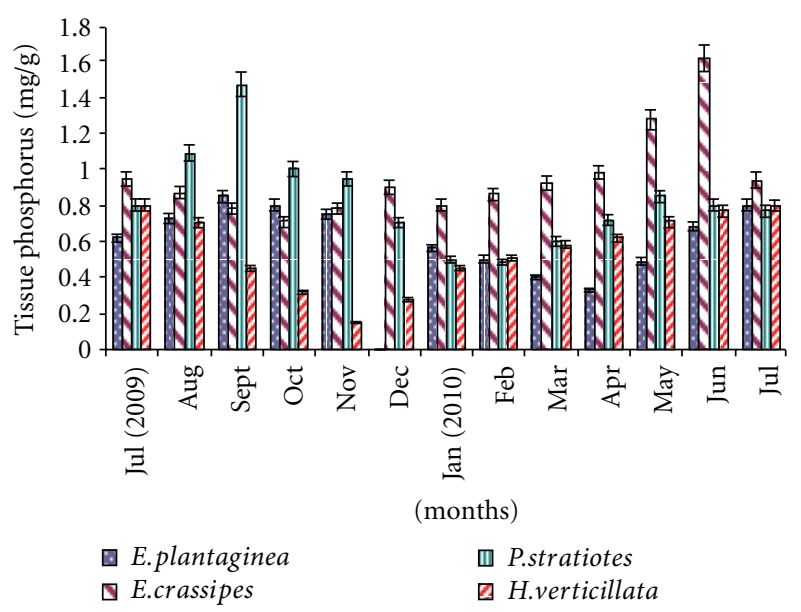

FIgure 5: Monthly variation in tissue phosphorus content (mg/g) of plants Eleocharis plantaginea, Eichhornia crassipes, Pistia stratiotes and Hydrilla verticillata from Kabar wetland.

period. Mean tissue $\mathrm{P}$ contents of the four plants varied in the order Pistia $>$ Eichhornia $>$ Eleocharis $>$ Hydrilla being $1.06 \pm 0.22,0.95 \pm 0.24,0.6 \pm 0.16$, and $0.55 \pm 0.21 \mathrm{mg} / \mathrm{g}$ dry weight $(\mathrm{dw})$, respectively. Eleocharis and Pistia both showed their accumulation peaks in the month of September. For Eichhornia this peak was achieved in June and for Hydrilla in July. The variation in the tissue $\mathrm{P}$ content was highly significant $(P=0.0000)$ whereas variation with season was insignificant $(P=0.7016)$. 
TABle 2: Relationship between total P (TP) in plant biomass with DIP in water (DP) and total P in sediment (SP) of Kabar. The squared multiple of correlation coefficient $\left(R^{2}\right)$ and $\mathrm{F}$ statistics are also shown with multiple regression analysis.

\begin{tabular}{lccc}
\hline Plants of Kabar wetland & Regression equation & $R^{2}$ & $F$ \\
\hline E. crassipes & $\mathrm{TP}=1.10-1.267 \mathrm{DP}+0.804 \mathrm{SP}$ & $0.76^{\mathrm{ns}}$ & $14.48^{\mathrm{c}}$ \\
E. plantaginea & $\mathrm{TP}=0.2+0.481 \mathrm{DP}+0.380 \mathrm{SP}$ & $0.64^{\mathrm{ns}}$ & $8.11^{\mathrm{b}}$ \\
H. verticillata & $\mathrm{TP}=3.16-0.931 \mathrm{DP}+0.587 \mathrm{SP}$ & $0.41^{\mathrm{b}}$ & $3.16^{\mathrm{ns}}$ \\
P. stratiotes & $\mathrm{TP}=0.83-0.848 \mathrm{DP}+1.063 \mathrm{SP}$ & $0.53^{\mathrm{b}}$ & $5.12^{\mathrm{a}}$ \\
\hline
\end{tabular}

$R^{2}$ and $F$ values are significant: ${ }^{\mathrm{a}} P<0.05,{ }^{\mathrm{b}} P<0.01,{ }^{\mathrm{c}} P<0.001$ with d.f. 2,9 for E. crassipes, E. plantaginea, $H$. verticillata and $P$. stratiotes

ns Not significant.

Table 3: Statistical evaluation of variation in Pistia tissue P, phosphate uptake rate and biomass using analysis of variance (ANOVA).

\begin{tabular}{lcc}
\hline \multirow{2}{*}{ Variables } & \multicolumn{2}{c}{ Sources of variability } \\
& Incubation period & Supplied phosphate \\
\hline Tissue P & 0.053 & $\mathbf{0 . 0 0 0 0}$ \\
Phosphate uptake rate & 0.3644 & $\mathbf{0 . 0 0 0 0}$ \\
Biomass & 0.1283 & $\mathbf{0 . 0 0 0 0}$ \\
\hline
\end{tabular}

Effects of incubation period and supplied phosphate have been expressed as $P$-values. Values in bold indicate significant differences at $P<0.0001$.

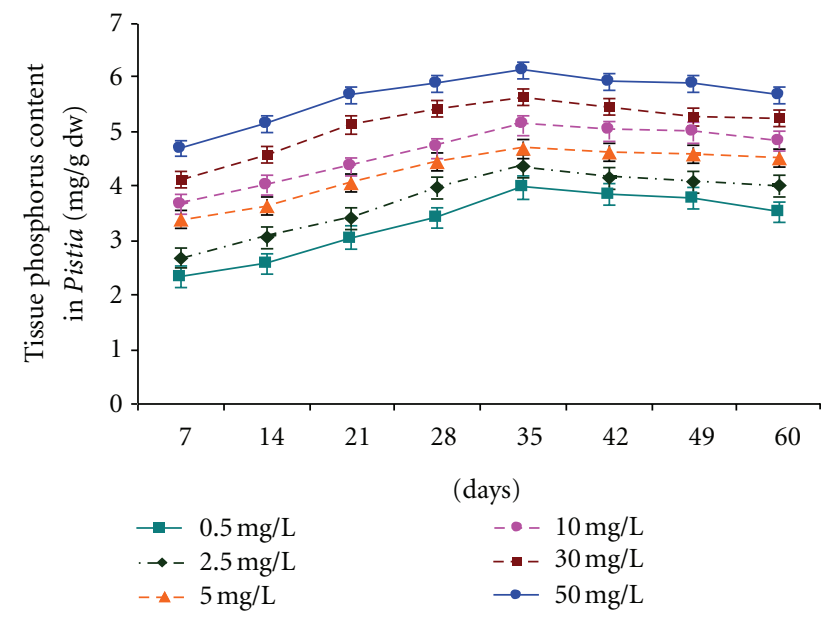

Figure 6: Tissue phosphorus content (mg/g dry weight) of Pistia stratiotes during the study period.

The relationship between plant tissue P and DIP and TP in Kabar was analyzed using multiple regression analysis. Sediment TP emerged as the stronger factor influencing tissue $\mathrm{P}$ content of the study plants in all except $E$. plantaginea (Table 2).

3.2. Luxury Uptake of Phosphate by Pistia stratiotes. Tissue accumulation of P in Pistia and the uptake rates of phosphate in the seven experimental basins are depicted in Figures 6 and 7, respectively. Pistia accumulated $6.12 \pm 0.95 \mathrm{mg} / \mathrm{g} \mathrm{dw} \mathrm{P}$ in 35 days in the basin with the highest phosphate supply $(50 \mathrm{mg} / \mathrm{L})$ indicating a high uptake rate at $1.6 \mathrm{~g} \mathrm{P} / \mathrm{m}^{2} /$ day. Supplied P had a highly significant effect on the P content of Pistia tissues $(P=0.0000)$ and on the uptake rate

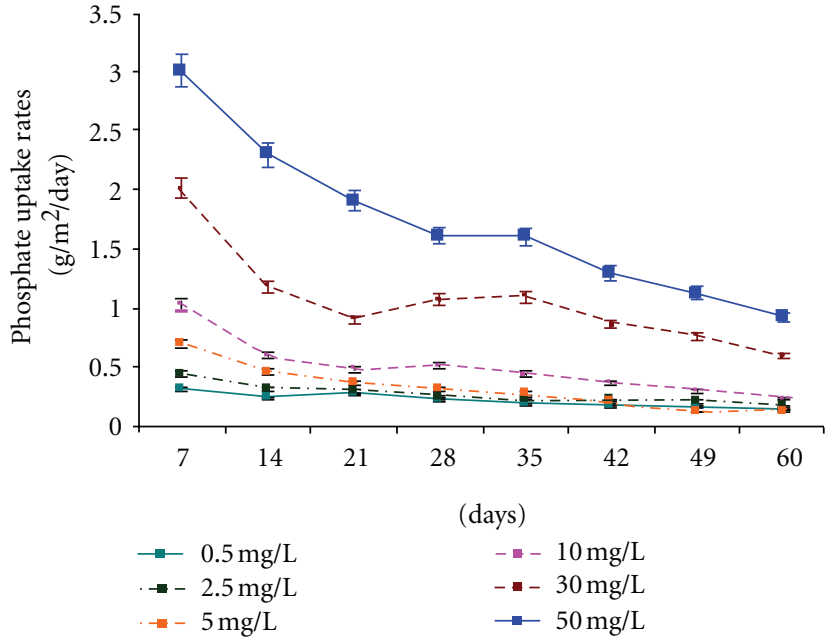

Figure 7: Phosphate uptake rates $\left(\mathrm{g} / \mathrm{m}^{2} /\right.$ day $)$ in the experimental basins.

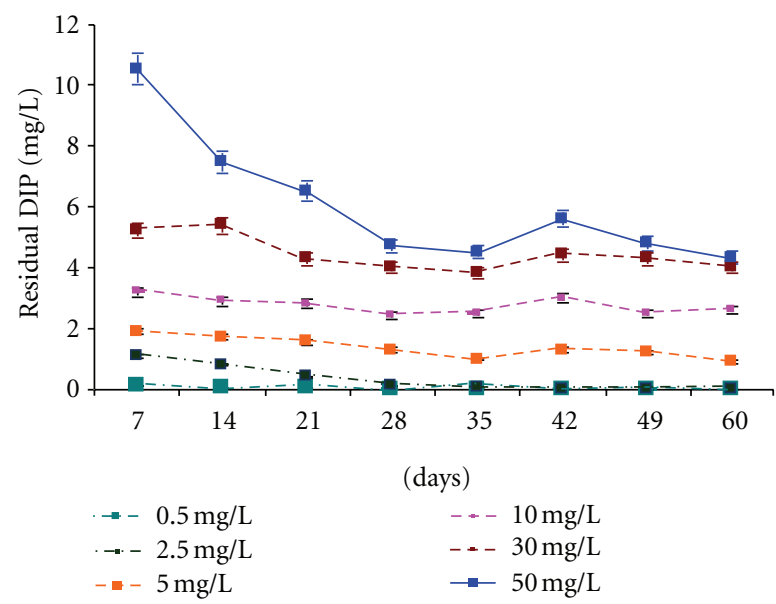

Figure 8: Residual DIP (in mg/L) in the experimental basins.

$(P=0.0000)$ (Table 3$)$. Incubation period was revealed not to have a statistically significant effect either on tissue phosphorus $(P=0.053)$ or on the uptake rate $(P=0.3645)$.

Residual DIP in the experimental basins has been depicted in Figure 8. At lower doses, 100\% phosphate removal occurred within 4 weeks. At the highest dose $(50 \mathrm{mg} / \mathrm{L})$, the residual DIP level reached $4.32 \pm 0.22 \mathrm{mg} / \mathrm{L}$ at the end 
TABle 4: Correlation coefficients $(r)$ among the luxury uptake of $\mathrm{P}$ (or total $\mathrm{P}$ in plant tissue) and residual DIP (or left over $\mathrm{P}$ ) in the experimental basins supplied with five different $\mathrm{P}$ concentrations (i.e., 0.5, 2.5, 5, 10, 30, and $50 \mathrm{mg} / \mathrm{L}$ ).

\begin{tabular}{lccccc}
\hline & \multicolumn{5}{c}{$\begin{array}{c}\text { Residual DIP in experimental basins } \\
\text { P Supply (in mg/L) }\end{array}$} \\
\hline $\begin{array}{l}\text { Total P in } \\
\text { plant } \\
\text { tissue }\end{array}$ & 0.5 & 2.5 & 5 & 10 & 30 \\
\hline
\end{tabular}

${ }^{a}$ Correlation is significant at 0.0001 level ( 1 tailed).

${ }^{\mathrm{b}}$ Correlation is significant at 0.005 level ( 1 tailed).

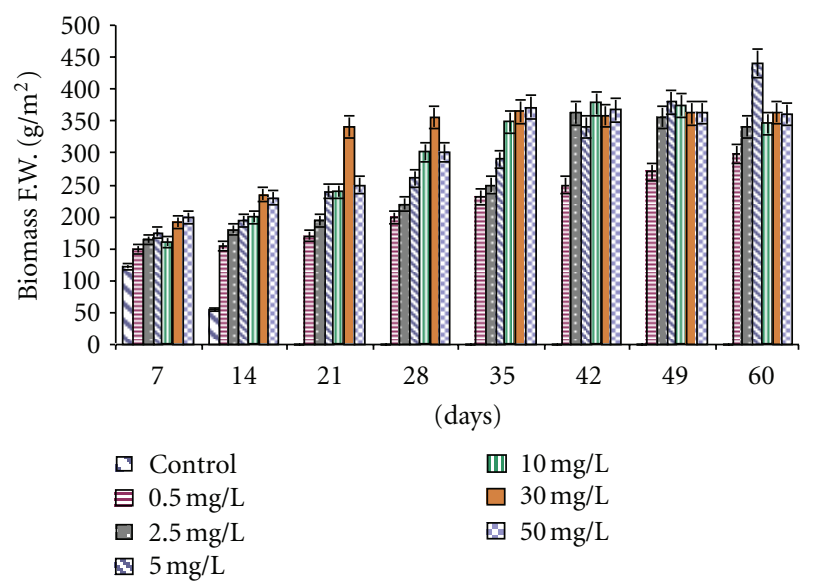

Figure 9: Fresh weight (F.W.) biomass $\left(\mathrm{g} / \mathrm{m}^{2}\right)$ variation in Pistia stratiotes during the study period.

of 60 days which amounts to $91.36 \%$ removal efficiency. Pearson's correlation coefficients (r) between the accumulated total phosphorus in P. stratiotes and residual DIP in the experimental basins with five different supplies of $\mathrm{P}$ are presented in Table 4. A strong negative correlation $(-0.96 \leq r \leq-0.72)$ was obtained between the two parameters.

3.3. Effect of Phosphate Supply on Biomass of Pistia stratiotes. Total weight of root and shoot was noted. Fresh weight biomass increase in Pistia stratiotes has been depicted in Figure 9. The seven phosphate dosages had a highly significant effect on the biomass increase $(P<0.001)$ (Table 3$)$. Multiple regression analysis revealed higher dependence of fresh weight biomass increase on incubation period than on the supplied DIP (Table 5). Growth in the control tanks that had been kept devoid of phosphate ceased beyond the second week of incubation emphasizing the critical role played by phosphate in plant metabolism and biomass increase. In the rest of the experimental basins, the mean biomass increase was by $107.49 \%$.

Multiple regression analysis studied the extent of dependence of tissue $\mathrm{P}$ content on plant biomass and residual DIP (Table 6). Biomass uniformly remained the stronger factor affecting the tissue $\mathrm{P}$ content.
TABLe 5: Relationship between total tissue P of Pistia stratiotes (TP), plant biomass (B), and residual dissolved inorganic P (RP) with incubation days (D) and DIP supply in the experimental basin. The squared multiple of correlation coefficient $\left(R^{2}\right)$ and $\mathrm{F}$ statistics are also shown with multiple regression analysis.

\begin{tabular}{|c|c|c|c|}
\hline Parameters & Regression equation & $R^{2}$ & $F$ \\
\hline $\begin{array}{l}\text { P Tissue } \\
\text { storage }\end{array}$ & $\mathrm{TP}=0.0742+0.166 \mathrm{D}+0.841 \mathrm{P}$ & $0.998^{\mathrm{b}}$ & $859.9^{\mathrm{b}}$ \\
\hline Biomass & $\mathrm{B}=83.92+1.823 \mathrm{D}-0.952 \mathrm{P}$ & $0.94^{\mathrm{a}}$ & $25.45^{\mathrm{a}}$ \\
\hline $\begin{array}{l}\text { Residual P } \\
\text { in Basin }\end{array}$ & $\mathrm{RP}=-0.282+0.929 \mathrm{D}+0.021 \mathrm{P}$ & $0.90^{\mathrm{b}}$ & $13.636^{\mathrm{a}}$ \\
\hline
\end{tabular}

$R^{2}$ and $F$ values are significant: ${ }^{\mathrm{a} P}<0.05,{ }^{\mathrm{b}} P<0.001$, with d.f. 2,3 for biomass, phosphorus tissue storage and residual phosphorus in basin.

\section{Discussion}

Nutrient dynamics in any wetland is influenced or dominated by some basic processes like transport, transformation and storage, and release and removal. Transport of suspended solids and particulate bound nutrients is highly dependent on the inflow regime of wetland. The inflow regime of the studied wetland is its connection with river Buri Gandak and other water bodies like the Bikrampur Chaurs and Nagri Jheel in the late monsoon months [35]. The elevated P contents of these inflow water bodies cause the enhanced influx of $\mathrm{P}$ in Kabar. The other key processes in the nutrient dynamics like transformation and release by microbes, storage in sediments, and uptake and accumulation in aquatic plants are complex. The removal through accumulation is directly dependent on amount of nutrient in the water column. In this study also, the tissue $\mathrm{P}$ content of the four species studied peaked in the late summer and rainy season (Figure 5), corresponding to the peak in the TP and DIP contents of water at both depths and in the sediment total P of Kabar wetland (Figures 2, 3, and 4).

The DIP and TP contents did not vary significantly with changing water depth. This ensured that the four species studied, received equal apportions of the macronutrient. The difference in the tissue P content of the four plants studied was highly significant, justifying the selection of Pistia for further studies.

An interesting aspect here is the marginal edge that Pistia displays over Eichhornia crassipes in tissue accumulation of 
TABLE 6: Relationship between total P (PTS) stored in P. stratiotes with plant biomass (B) and residual DIP in the experimental basin (RP). The squared multiple of correlation coefficient $\left(R^{2}\right)$ and $\mathrm{F}$ statistics are also shown with multiple regression analysis.

\begin{tabular}{lccc}
\hline Supplied DIP (in mg/L) & Regression equation & $R^{2}$ & $F$ \\
\hline 0.5 & PTS $=15.59-1.494 \mathrm{~B}-1.737 \mathrm{RP}$ & $0.64^{\mathrm{b}}$ & $4.46^{\mathrm{ns}}$ \\
2.5 & PTS $=7.23+0.112 \mathrm{~B}-0.627 \mathrm{RP}$ & $0.49^{\mathrm{ns}}$ & $1.92^{\mathrm{ns}}$ \\
5 & PTS $=6.93+0.669 \mathrm{~B}-0.418 \mathrm{RP}$ & $0.52^{\mathrm{b}}$ & $2.67^{\mathrm{ns}}$ \\
10 & PTS $=2.21+1.032 \mathrm{~B}-0.142 \mathrm{RP}$ & $0.96^{\mathrm{ns}}$ & $54.49^{\mathrm{c}}$ \\
30 & PTS $=13.65+0.669 \mathrm{~B}-0.369 \mathrm{RP}$ & $0.7^{\mathrm{ns}}$ & $5.94^{\mathrm{a}}$ \\
50 & PTS $=23.12+0.516 \mathrm{~B}-0.722 \mathrm{RP}$ & $0.86^{\mathrm{ns}}$ & $15.82^{\mathrm{b}}$ \\
\hline
\end{tabular}

$R^{2}$ and $F$ values are significant: ${ }^{\mathrm{b}} P<0.05,{ }^{\mathrm{b}} P<0.01,{ }^{\mathrm{c}} P<0.001$ with d.f 2,5 for the supplied Phosphorus of $0.5,2.5,5,10,30$, and $50 \mathrm{mg} / \mathrm{L}$.

${ }^{\mathrm{n}}$ Not significant.

$\mathrm{P}$ as depicted in Section 3.1. The same has not been demonstrated in previous studies. Tucker and DeBusk [36], Agami and Reddy [34], and Tripathi et al. [37] report greater growth efficiency and biomass increase of E. crassipes as compared to Pistia. However, Polomski et al. [23] demonstrated that Pistia absorbed slightly more tissue $\mathrm{P}$ as compared to E. crassipes (3.07 mg/g dw versus $2.53 \mathrm{mg} / \mathrm{g} \mathrm{dw}$ ). Tucker and DeBusk [36] reported greater tissue nitrogen content of $P$. stratiotes as compared to E. crassipes.

Pistia stratiotes has been widely reported as a $\mathrm{P}$ bioremediating agent, but the reports in this paper present Pistia as more efficient than reported before. For instance Zimmels et al. [38] reported $25 \%$ to $38.4 \%$ total P removal efficiency of Pistia when it was exposed to $17.2 \mathrm{mg} / \mathrm{L} \mathrm{TP}$ for 14 days as against the efficiency of $43.3 \%$ reported by us at the end of 14 days. $\mathrm{Lu}$ et al. [24] reported an efficiency of only $22.39 \%$ and $31.08 \%$ at the end of 19 days when exposed to 0.63 and $0.77 \mathrm{mg} / \mathrm{L} \mathrm{TP}$, respectively. It was also demonstrated by $\mathrm{Lu}$ et al. [24] that Pistia accumulated $3 \mathrm{mg} / \mathrm{g} \mathrm{dw} \mathrm{P}$ in its tissues, which is nearly half the maximal tissue storage reported by us $(6.12 \mathrm{mg} / \mathrm{g} \mathrm{dw})$ but is comparable to our report of $3.14 \mathrm{mg} / \mathrm{g} \mathrm{dw}$ tissue $\mathrm{P}$ at the end of 21 days in the $0.5 \mathrm{mg} / \mathrm{L}$ tank.

Our results may be compared with those of Polomski et al. [23] who exposed Pistia to up to $6.77 \mathrm{mg} / \mathrm{L}$ TP in nursery runoff for 8-weeks and observed 93\%-96\% TP removal efficiency and $3.07 \mathrm{mg} / \mathrm{g} \mathrm{dw}$ tissue $\mathrm{P}$ at the conclusion of the experimental period.

When compared to other wetland plants, Pistia accumulated significantly high amounts of P. Afrous et al. [21] reported the accumulation of $10.8 \mathrm{~g} / \mathrm{m}^{2} \mathrm{P}$ by Phragmites australis which is much less than the amount biosorbed by Pistia $\left(56.5 \mathrm{~g} / \mathrm{m}^{2}\right)$ (Figure 6). Typha, Phragmites, Scrispus, and Junucus were reported to accumulate between 1.4 and $37.5 \mathrm{~g} / \mathrm{m}^{2}$ P by Reddy and DeBusk [22]. The fibrous root system of Pistia makes it an efficient nutrient biosorbent [8].

The absorption of phosphate by plants is also affected by the concentration of other nutrients like nitrogen [21] and zinc $[39,40]$ in the nutrient medium. Since the present study utilized the Hoagland's solution for cultivating Pistia, optimum amounts of all the required nutrients were present.

The residual DIP in the experimental basins diverged on some occasions from its usual descending trend (Figure 7). These insignificant divergences may be the outcome of microbial activity or may be due to the release of nutrients during senescence [41-43]. A strong negative correlation was obtained between tissue P content of Pistia and the residual DIP in the experimental basins. This supported the fact that the removal of phosphate from the experimental basins was indeed by biological uptake and not chemical precipitation, hence the negative correlation coefficient $(r)$ value approaching -1 .

Further implications of this study lies in the successful usage of $P$. stratiotes for the restoration of actual nutrientpolluted wetlands. Such wetlands that are already suffering from algal blooms and biodiversity loss may have to undergo one manual harvest of the algal population, followed by the establishment of Pistia monoculture. Being a free-floater, Pistia population will then have to be harvested time to time [44]. Later, the plant body may be harvested and put to use as animal feed or source of fuel [45]. Once water phosphorus levels are reduced to normal, Pistia may be removed altogether and a healthy biodiversity may be allowed to develop in the restored wetland.

Hence, at the end of this study we conclude that Pistia is an efficient $\mathrm{P}$ accumulator as compared to several other wetland species like Phragmites, Typha, and so forth. Its efficiency becomes better in subtropical ecosystems where it can out compete even efficient growers like E. crassipes. It may be utilized for the amelioration of subtropical wetlands that are battling enhanced phosphate influx.

\section{Acknowledgments}

This research was supported by University Grants Commission, New Delhi (F.no. 33-169/2007 SR) and Council of Scientific and Industrial Research, New Delhi (38(1165)/07/EMR II), for which the authors are grateful. The second and third authors are thankful to University Grants Commission, New Delhi and Council of Scientific and Industrial Research, New Delhi, respectively, for Junior Research Fellowship grants. The authors thank the reviewers for their positive comments on our manuscript.

\section{References}

[1] K. R. Reddy, R. H. Kadlec, E. Flaig, and P. M. Gale, "Phosphorus retention in streams and wetlands: a review," Critical Reviews in Environmental Science and Technology, vol. 29, no. 1, pp. 83-146, 1999. 
[2] U. Pierrou, "The global Phosphorus cycle," in Nitrogen, Phosphorus and Sulphur-Global Cycles, B. H. Svensson and R. Soderlund, Eds., vol. 22 of SCOPE Report 7, Ecological Bulletin, pp. 75-88, Swedish Natural Science Research Council, Stockholm, Sweden, 1976.

[3] T. Yoshimura, J. Nishioka, H. Saito, S. Takeda, A. Tsuda, and M. L. Wells, "Distributions of particulate and dissolved organic and inorganic phosphorus in North Pacific surface waters," Marine Chemistry, vol. 103, no. 1-2, pp. 112-121, 2007.

[4] E. B. Welch and T. Lindell, "Nutrient cycles," in Ecological Effects of Wastewater Applied limnology and Pollutant Effects, pp. 54-81, Cambridge University Press, 2nd edition, 1992.

[5] I. C. R. Holford, "Soil phosphorus: its measurement, and its uptake by plants," Australian Journal of Soil Research, vol. 35, no. 2, pp. 227-239, 1997.

[6] N. Powell, A. Shilton, Y. Chisti, and S. Pratt, "Towards a luxury uptake process via microalgae-defining the polyphosphate dynamics," Water Research, vol. 43, no. 17, pp. 4207-4213, 2009.

[7] S. Eixler, U. Karsten, and U. Selig, "Phosphorus storage in Chlorella vulgaris (Trebouxiophyceae, Chlorophyta) cells and its dependence on phosphate supply," Phycologia, vol. 45, no. 1, pp. 53-60, 2006.

[8] A. P. Kuhl, "Phosphorus," in Algal Physiology and Biochemistry, W. D. P. Stewart, Ed., pp. 636-654, Blackwell Scientific, Oxford, UK, 1974.

[9] S. Miyachi, R. Kanai, S. Mihara, S. Miyachi, and S. Aoki, "Metabolic roles of inorganic polyphosphates in Chlorella cells," Biochimica et Biophysica Acta, vol. 93, no. 3, pp. 625-634, 1964.

[10] S. Miyachi and S. Miyachi, "Modes of formation of phosphate compounds and their turnover in Chlorella cells during the process of life cycle as studied by the technique of synchronous culture," Plant and Cell Physiology, vol. 2, no. 4, pp. 415-424, 1961.

[11] S. Miyachi and H. Tamiya, "Distribution and turnover of phosphate compounds in growing Chlorella cells," Plant and Cell Physiology, vol. 2, no. 4, pp. 405-414, 1961.

[12] N. Powell, A. N. Shilton, S. Pratt, and Y. Chisti, "Factors influencing luxury uptake of phosphorus by microalgae in waste stabilization ponds," Environmental Science and Technology, vol. 42, no. 16, pp. 5958-5962, 2008.

[13] J. E. Vermaat and M. Khalid Hanif, "Performance of common duckweed species (Lemnaceae) and the waterfern Azolla filiculoides on different types of waste water," Water Research, vol. 32, no. 9, pp. 2569-2576, 1998.

[14] E. Tylova-Munzarova, B. Lorenzen, H. Brix, and O. Votrubova, "The effects of $\mathrm{NH}_{4}{ }^{+}$and $\mathrm{NO}_{3}{ }^{-}$on growth, resource allocation and nitrogen uptake kinetics of Phragmites australis and Glyceria maxima," Aquatic Botany, vol. 81, no. 4, pp. 326-342, 2005.

[15] S. Irfan and Shardendu, "Dynamics of nitrogen in subtropical wetland and its uptake and storage by Pistia stratiotes," Journal of Environmental Biology, vol. 30, no. 6, pp. 977-981, 2009.

[16] Shardendu and R. S. Ambasht, "Relationship of nutrients in water with biomass and nutrient accumulation of submerged macrophytes of a tropical wetland," New Phytologist, vol. 117, no. 3, pp. 493-500, 1991.

[17] J. B. Bole and J. R. Allan, "Uptake of phosphorus from sediment by aquatic plants: Myriophyllum spicatum and Hydrilla verticillata," Water Research, vol. 12, no. 5, pp. 353-358, 1978.

[18] C. P. McRoy and R. J. Barsdate, "Phosphate absorption in eelgrass," Limnology and Oceanography, vol. 15, no. 1, pp. 6-13, 1970.
[19] J. W. Barko and R. M. Smart, "Mobilization of sediment phosphorus by submersed freshwater macrophytes," Freshwater Biology, vol. 10, no. 3, pp. 229-238, 1980.

[20] T. A. Debusk, J. E. Peterson, and K. R. Reddy, "Use of aquatic and terrestrial plants for removing phosphorus from dairy wastewaters," Ecological Engineering, vol. 5, no. 2-3, pp. 371390, 1995.

[21] A. Afrous, N. Hedayat, A. Liaghat, M. Mohammadpour, and M. Manshouri, "Accumulation and uptake of nitrogen and $\mathrm{P}$ by four species of aquatic plants under arid and semi-arid conditions of Dezful, Iran," World Applied Sciences Journal, vol. 10, no. 8, pp. 886-891, 2010.

[22] K. R. Reddy and W. F. DeBusk, "Nutrient storage capabilities of aquatic and wetland plants," in Aquatic Plants for Waste Treatment and Resource Recovery, K. R. Reddy and W. H. Smith, Eds., pp. 337-357, Magnolia Publishing, 1987.

[23] R. F. Polomski, M. D. Taylor, D. G. Bielenberg, W. C. Bridges, S. J. Klaine, and T. Whitwell, "Nitrogen and phosphorus remediation by three floating aquatic macrophytes in greenhouse-based laboratory-scale subsurface constructed wetlands," Water, Air, and Soil Pollution, vol. 197, no. 1-4, pp. 223232, 2009.

[24] Q. Lu, Z. L. He, D. A. Graetz, P. J. Stoffella, and X. Yang, "Phytoremediation to remove nutrients and improve eutrophic stormwaters using water lettuce (Pistia stratiotes L.)," Environmental Science and Pollution Research, vol. 17, no. 1, pp. 84-96, 2010.

[25] T. Chopin, H. Lehmal, and K. Halcrow, "Polyphosphates in the red macroalga Chondrus crispus (Rhodophyceae)," New Phytologist, vol. 135, no. 4, pp. 587-594, 1997.

[26] R. Portielje and L. Lijklema, "Kinetics of luxury uptake of phosphate by algae-dominated benthic communities," Hydrobiologia, vol. 275-276, no. 1, pp. 349-358, 1994.

[27] G. W. Fuhs and M. Chen, "Microbial basis of phosphate removal in the activated sludge process for the treatment of waste water," Microbial Ecology, vol. 2, pp. 119-138, 1975.

[28] A. Khoshmanesh, B. T. Hart, A. Duncan, and R. Beckett, "Luxury uptake of phosphorus by sediment bacteria," Water Research, vol. 36, no. 3, pp. 774-778, 2002.

[29] T. Panswad, A. Doungchai, and J. Anotai, "Temperature effect on microbial community of enhanced biological phosphorus removal system," Water Research, vol. 37, no. 2, pp. 409-415, 2003.

[30] A. K. Ghosh, N. Bose, K. R. P. Singh, and R. K. Sinha, "Study of spatio-temporal changes in the wetlands of north Bihar through remote sensing," in Proceedings of the 13th International Soil Conservation Organisation Conference (ISCO '04), Conserving Soil and Water for Society: Sharing Solutions. Paper no. 471, Brisbane, Australia, July 2004.

[31] J. Ebina, T. Tsutsui, and T. Shirai, "Simultaneous determination of total nitrogen and total phosphorus in water using peroxodisulfate oxidation," Water Research, vol. 17, no. 12, pp. 1721-1726, 1983.

[32] C. L. Langner and P. F. Hendrix, "Evaluation of a persulfate digestion method for particulate nitrogen and phosphorus," Water Research, vol. 16, no. 10, pp. 1451-1454, 1982.

[33] American Public Health Association (APHA), Standard Methods for Examination of Water and Waste Water, 21st edition, 2005.

[34] M. Agami and K. R. Reddy, "Competition for space between Eichhornia crassipes (Mart.) Solms and Pistia stratiotes L. cultured in nutrient-enriched water," Aquatic Botany, vol. 38, no. 2-3, pp. 195-208, 1990. 
[35] K. Ambastha, S. A. Hussain, and R. Badola, "Resource dependence and attitudes of local people toward conservation of Kabartal wetland: a case study from the Indo-Gangetic plains," Wetlands Ecology and Management, vol. 15, no. 4, pp. 287-302, 2007.

[36] C. S. Tucker and T. A. DeBusk, "Productivity and nutritive value of Pistia stratiotes and Eichhornia crassipes," Journal of Aquatic Plant Management, vol. 19, pp. 61-63, 198.

[37] B. D. Tripathi, J. Srivastava, and K. Misra, "Nitrogen and phosphorus removal-capacity of four chosen aquatic macrophytes in tropical freshwater ponds," Environmental Conservation, vol. 18, no. 2, pp. 143-147, 1991.

[38] Y. Zimmels, F. Kirzhner, and A. Kadmon, "Effect of circulation and aeration on wastewater treatment by floating aquatic plants," Separation and Purification Technology, vol. 66, no. 3, pp. 570-577, 2009.

[39] Y. G. Zhu, S. E. Smith, and F. A. Smith, “Zinc (Zn)-phosphorus (P) interactions in two cultivars of spring wheat (Triticum aestivum L.) Differing in p uptake efficiency," Annals of Botany, vol. 88, no. 5, pp. 941-945, 2001.

[40] C. Huang, S. J. Barker, P. Langridge, F. W. Smith, and R. D. Graham, "Zinc deficiency up-regulates expression of highaffinity phosphate transporter genes in both phosphate-sufficient and -deficient barley roots," Plant Physiology, vol. 124, no. 1, pp. 415-422, 2000.

[41] D. S. Nichols, "Capacity of natural wetlands to remove nutrients from wastewater," Journal of the Water Pollution Control Federation, vol. 55, no. 5, pp. 495-505, 1983.

[42] A. E. Richardson, "Soil microorganism and phosphorus availability," Soil Biota, pp. 50-62, 1994.

[43] R. Kröger, M. M. Holland, M. T. Moore, and C. M. Cooper, "Plant senescence: a mechanism for nutrient release in temperate agricultural wetlands," Environmental Pollution, vol. 146, no. 1, pp. 114-119, 2007.

[44] J. Vymazal, "Removal of nutrients in various types of constructed wetlands," Science of the Total Environment, vol. 380, no. 1-3, pp. 48-65, 2007.

[45] K. R. Reddy and W. F. De Busk, "Nutrient removal potential of selected aquatic macrophytes," Journal of Environmental Quality, vol. 14, no. 4, pp. 459-462, 1985. 

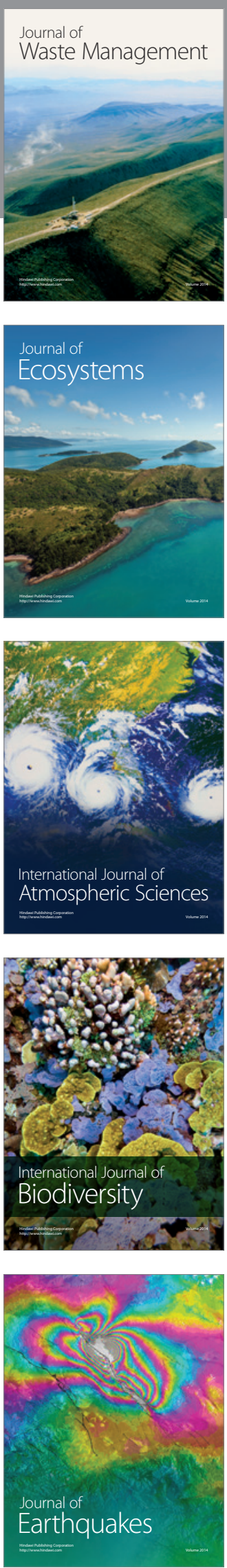
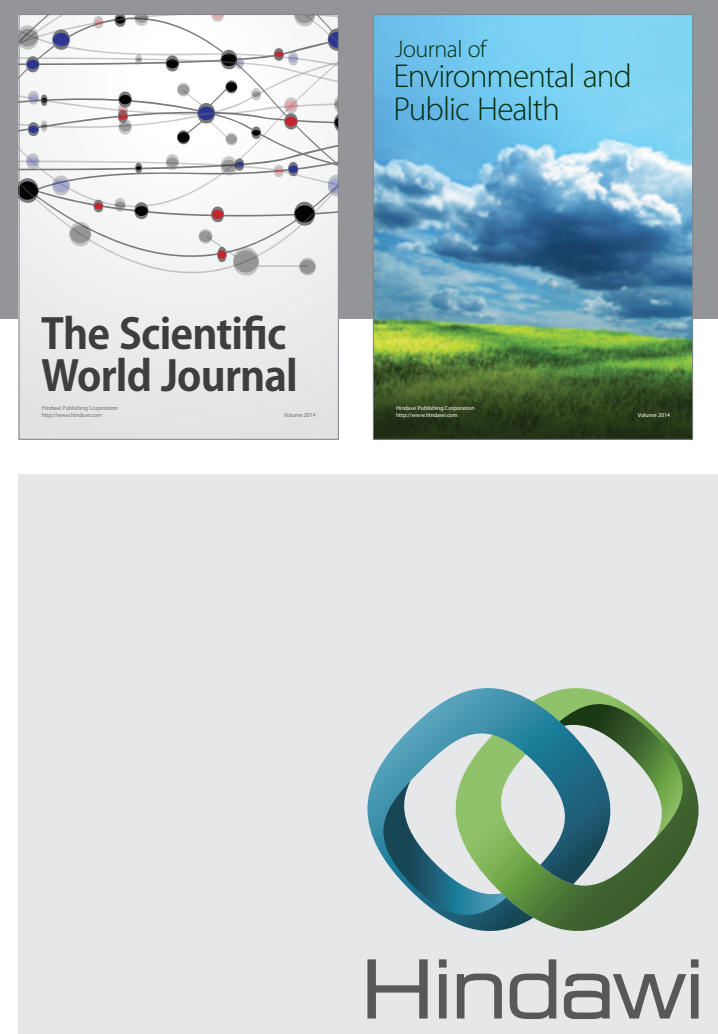

Submit your manuscripts at

http://www.hindawi.com
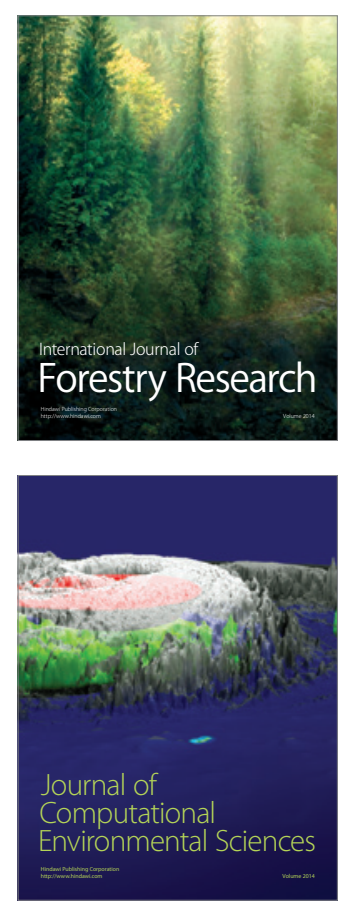
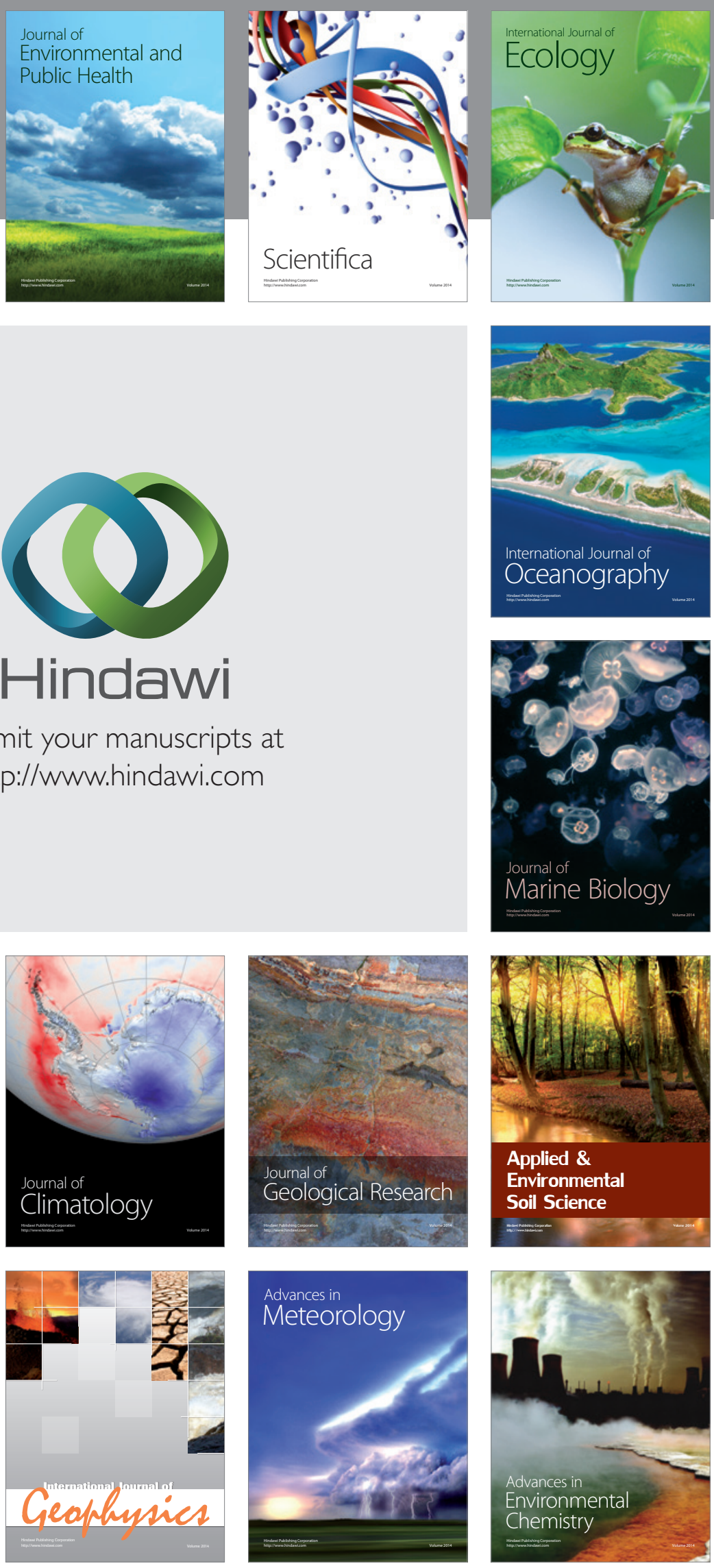